\title{
Learning and Cultural Experiences of Arab Muslim Graduate Students in a Canadian University
}

\author{
Gamal M. M. Mostafa \\ Al-Azhar University, Egypt \& University of Alberta, Canada \\ fgamal1@yahoo.com
}

\begin{abstract}
The purpose of the present study is to explore the experiences of Arab Muslim graduate students in the University of Alberta ( $U$ of $A$ ) regarding cultural differences and adjustment, language difficulties, supervision, differences of study system, and funding. Semi-structured interviews were conducted with five Arab Muslim graduate students from Egypt, Libya, Oman, Iraq and Kuwait. The findings of the study reveal that although students experience some difficulties adjusting to Canadian society, adjustment is made easier through their interaction with local Muslim communities and organizations such as mosques. In addition, respondents indicate the multicultural nature of Canadian society is an asset that helps them o-n and offcampus. Moreover, the presence of Arab Muslim students at the $U$ of A may help in correcting the image of Islam as a religion, distorted in the west, through interaction both academically and socially with other students. The study recommends greater cooperation between the university and Muslim cultural and religious organizations within Canadian society.
\end{abstract}

The religion of Islam urges its followers to seek science and knowledge, as the first verse revealed of the Holy Qur'an ${ }^{1}$ is "Read! In the name of your Lord, Who has created (all that exists)" (96-1), and Allah (a concept referring to God in Islam) says in the Holy Qur'an, "Are those equal, those who know and those who don't know" (39-9). Allah's Messenger (peace be upon him) said, "He who travels to seek any (beneficial) knowledge is considered as a person who is struggling in Jihad for the cause of Allah until he returns" (An-Nawawy, 1997, p. 418).

In addition to religious factors, Arab Muslim students, like other international students all over the world, choose to study abroad for many reasons. They may travel to attend universities internationally as Barker (1997) observes, for multiple specialist knowledges and the prestige of a "foreign" degree that qualifies them for better jobs with higher incomes (p. 108). As indicated in a report of The National Academies (2005), these factors are a combination of push and pull factors. Push factors refer to the features of the home environment that are viewed by prospective students as unsatisfactory, such as: restricted economic resources, fewer world-class institutions, degree of involvement in the world community, fewer doctoral and postdoctoral programs, lack of availability of specializations, limited access to funding (especially for junior investigators), poor career prospects, and adverse social or political conditions. On the other hand, pull factors are desirable features of a destination country, such as: better academic and technological facilities, better financial support, prestige of a foreign degree, social links and personal

\footnotetext{
${ }^{1}$ Translations of Qur'anic verses are taken from: The Holy Qur'an: English Translation of the meanings and commentary, Translated by Abdullah yusuf Ali, Saudi Arabia:King Fahd Holy Qur'an Printing Complex.
}

Journal of Contemporary Issues in Education, 2006, 1(1), pp.36-53

ISSN 1718-4770 C 2006 University of Alberta

http://ojs.educ.ualberta.ca/index.php/jcie/ 
recommendations, life in a diverse culture, better working conditions, more opportunities for employment, the willingness of employers to hire well-qualified foreigners, and potential of higher salaries (p. 103).

It is well observed that globalization has impacted many fields in different societies including education. Cultural diversity is one of the main features of universities and higher education organizations all over the world. Cultural diversity is a direct result of university policies designed to attract more international students, undergraduates and postgraduates alike. The degree of this diversity, between the cultures of international students and that of the host country, affects the cultural and learning experiences of these students. There are mutual benefits for hosting international students at universities, as these students benefit from educational and cultural opportunities available in a different academic environment. In the same way, the cultural diversity within the international student population enriches the academic environment at these universities (Nelson, Nelson \& Malone, 2004; Mostafa, 2001, p. 69-73; Wisker, 2005, p. 191).

Amongst the benefits for these students is cross- cultural enrichment, development of foreign language competencies, awareness of some political issues, developing the students' technical skills, and guarantee for a future career (Mostafa, 2001, p. 69-72). Green and Powell (2005) refer to the importance of international graduate students and the "well-being of research" in the host country, "the income of most universities," and the research and educational issues students bring to their supervisors (p. 158-159). International graduate students, as stated in the report of The National Academies (2005), contribute to American (and other host countries') societies in many aspects: academically, economically, and through fostering global and cultural knowledge that leads to understanding necessary for effective leadership, competitiveness and security in the United States (US). Moreover, this report found that international students and scholars have promoted American science and engineering as evidenced by numerous new inventions, publications, and, Nobel Prize winners (p.3, 5).

Todd (1997) emphasizes this point by inquiring whether international students should be considered as "problematic" because of their increased demand on supervisors' time and effort, or to be considered as an opportunity as supervisors gain a better understanding about teaching and learning in finding ways to meet student educational and cultural needs (p.174). Selvadurai (1992) emphasizes that colleges and universities welcome international students and scholars to maintain universal value of education and to further international understanding. Education is a means of achieving academic and personal goals; moreover, it is an instrument for the economic, social and political development of emerging countries. Hence, international students represent a source of cultural diversity, enlightenment and revenue.

Many studies consider international students disadvantaged given that English is not their mother tongue. Furthermore, differences between their educational backgrounds and those of the educational systems in which they are enrolled may pose difficulties not encountered by domestic students (Leder \& Forgasz, 2004; Mostafa, 2001). Experiences of international graduate students, in particular, may be more acute as there is intense pressure to succeed because of expectations commensurate with scholarships made available to them through their occupations in their native countries, to which they will return. Many students experience different challenges such as language barriers that may affect communication, financial barriers and lack of family support, isolation, loss of 
social status, culture shock, managing workload, and/or having sufficient academic background in their area of specialization (Myles \& Cheng, 2003). In addition to these experiences, many international students work under parental pressures to overcome educational failures in their home environments (Mostafa, 2001; Leder \& Forgasz, 2004).

Cultural adjustment of international students depends on the similarities and differences between a students' culture and that of the host country. A study investigating the socialization of international students in an American university revealed that those who looked like and were culturally similar to Americans interacted with them at least once weekly, while a majority of those who were culturally dissimilar socialized with Americans less often (Trice, 2004). In the case of Arab Muslim graduate students in Canadian society, the experiences of these students will be acute because of the huge differences between Arabic Islamic and Canadian cultures.

Arab (Muslim) students, like Middle Eastern students elsewhere, live close together and prefer interaction with people from their origin countries thus creating sub-cultural groups. They usually have organizations and religious places which they frequent to preserve Islamic heritage and to instill Islamic values and traditions within the Muslim community (Alreshoud \& Koeske, 1997; Hodge, 2002). Muslims in Canada have access to many religious and social organizations. In Edmonton, there are six mosques. Organizations include the Muslim Community of Edmonton (MCE), Canadian Society of Muslims, Islamic Circle of North America (ICNA), Islamic Society of North America (ISNA), Canadian Council on American-Islamic Relations (CAIR-CANADA), The Canadian Islamic Congress, Muslim Association of Canada (MAC) and Islamic Supreme Council of Canada (ISCC).

International students represent both a source of cultural interaction and, at the same time, present a cultural challenge to the university community. These students have special issues and circumstances that differ from those of their counterparts relating to cultural differences, cultural adjustment, language difficulties, a new system of study, and financial resources. "Students working at a distance,... and those whose learning cultural background differs from that of their supervisors or whose English doesn't allow them to express their thoughts clearly are in a very different position to those whom we meet regularly" (Wisker, 2005, p.19).

\section{Research Questions}

The study tries to answer the following principal question: What are the learning and cultural experiences of the Arab Muslim graduate students at the University of Alberta? Additionally, four specific sub-questions emerged from this fundamental question Namely: What are the experiences of the Arab Muslim graduate students attending the University of Alberta with respect to their perceptions of differences in the educational systems, in their supervisory experiences, in their cultural adjustment to Canadian cultures and communities, and in their English communication on and off campus?

\section{Literature review}

This review will focus on discussion and comments concerning studies of these core ideas: differences in academic systems, student supervision, English language difficulties, cultural differences, and adjustments. 


\section{Differences in academic systems}

Supervisors, as well as all members of the departments where international graduate students are enrolled, need to be aware that students come with culturally influenced strategies of conducting research and "culturally-influenced constructions of knowledge" (Wisker, 2005, p. 192). Changing the academic culture of international graduate students is a multi-dimensional and challenging experience as it requires continuous transitions between two languages and academic systems (Cadman, 2000). A group of Arab Muslim students at a Canadian university state, "they make great efforts to overcome problems caused by the cultural and educational differences" (Abukhattala, 2004). Bullen and Kenway (2003) emphasize the effects of difference between home and foreign academic systems on teaching and learning styles.

One of the main differences within educational systems in different countries is the role of the supervisor. In some educational environments, a supervisor is the main source of knowledge and represents a symbol of infallibility. Some international students, therefore, may expect much guidance, support and participation from their supervisors. On the other hand, they may avoid entering debates with their supervisors assuming that everything a supervisor says is always correct and unargumentative, and that the role of the student is to follow the instructions of their supervisor (Todd, 1997, p. 177; Wisker, 2005, p.194-195).

Results of a Graduate Student Satisfaction Survey at the University of Maryland (2000), show that international graduate students are less likely to be satisfied with the quality of instruction by both full-time and part-time faculty. In addition, participants indicated lower satisfaction with the quality of their academic program compared to noninternational students. International students were also significantly less satisfied with class size relative to their needs, course availability, and information provided by instructors with regard to course requirements and objectives. It should also be noted that on all the academic experience variables, greater percentages of international than noninternational students indicated feeling neutral feelings.

Abukhattala (2004) asserts that Arab Muslim graduate students encounter educational differences in student-teacher relationship, teaching methodology, democratic dialogue in classroom, teaching and learning foreign languages, examinations, research and library facilities, and interactions in classroom. They also experience cultural issues regarding the Canadians' perceptions of the Muslim women dress (hijab) and sex-segregated relationships.

Fourteen international graduate students from different regions of the world enrolled in an American university stated that they experienced differences in their education in the US and that of their home countries. Amongst these differences include: knowledge as valued in the US is knowledge that is rational, objective and logical, interaction in class is highly valued as a learning method, there is a focus on independent learning, informality of relationship between students and their instructors, and increased availability of facilities and technology (Eland, 2001, p. 84-88).

\section{Student supervision:}

One of the main difficulties of supervising international students is the nature of the relationship between a student and his or her supervisor, especially when there is much dissimilarity between their academic cultures. Mostafa (2004) indicates that although the supervisory relationship is a two-way relationship, the supervisor plays a 
principal role in the success of this relationship (p. 108). Supervising overseas students requires additional time and effort on the part of the supervisor due academic and cultural differences. In addition, the relationship is influenced by the student's expectations of the supervisor. In some cultures, it is important to show deference to those in authority. Students coming from such cultures need guidance to overcome possible assumptions regarding the informality of supervisory relationship. The issue of age (and authority) in Asian and Middle Eastern culture is of particular importance in interpersonal relationships and can cause great social awkwardness in student/supervisor relationship. (Maheshwari \& Malfroy, 2001, p. 255-256)

The supervisor of an international student need take into consideration that, in addition to the difficulties those students might encounter, there are common problems associated with all doctoral-level students at the beginning of their programs. These problems may include over- ambition and enthusiasm, resisting or avoiding engagement in theoretical debates, partial or naïve understanding of the field of their proposed work, and/or a student's belief that his/her PhD will change the world and solve all problems in the field. In addition, a students' research topics and questions may be ambiguous or insufficiently focused. Furthermore, the supervisor of an international student should be aware of a student's "research education" as universities in different countries provide their students with different levels of research education and/or training. As such, a supervisor should become familiar with a student's background to determine any formal requirements needed for a successful supervisory relationship (Epstien, Boden \& Kenway, 2005, p. 87-90).

\section{English language difficulties}

Studying in a language other than the learner's mother tongue is one of the main difficulties facing international students which may negatively affect their performance. A number of studies investigating experiences of international students regarding foreign language difficulties showed a lack of language competence as a substantial problem (Mostafa, 2001; Selvadurai, 1992; Cammish, 1997; Macrae, 1997). Burns (1991) indicates "many students enter the host country believing that they speak the queen's English only to find that their accent, grammar, pronunciation and that of their host don't match and both parties have difficulty understanding the other " (cited in Scheyvens, Wild \& Overton, 2003).

Wisker (2005) emphasized the negative effect of language difficulties on international student performance as studying in a second language may obstruct thinking and articulation, and affect the complexity of thought processes, especially at $\mathrm{PhD}$ level. It can also affect the supervisory relationship when the level of discussion does not reflect the level of thought processes of either party, which may cause further misinterpretation. Language support and development systems are essential for both students and their supervisors (p. 194).

Language barriers influencing international students are not restricted to academic environments inside the classeroom or in discussions with supervisors, but go beyond into interpersonal relationships and everyday life interactions. Yeh and Inose (2003) found English to be linked to culture noting that European international students were less likely to experience acculturative distress than were students from other geographic regions. Trice (2004) insists weak English language skills may lead to negative outcomes. The poorer the student's English, the less adapted an international students was to the 
host culture, the less satisfied they were with their social and community relations, and, the more difficulty they had making friends. Furthermore, students with weak English language skills have more difficulty communicating with native speakers or other international students. The difficulties of language may vary according to whether it is a receptive language or a productive language. Receptive language - reading and listeningis easier than productive language - writing and speaking. However, developing good oral communication skills is necessary for international graduate students to become members of the academic environment or department, to participate in debates and discussions, or, to engage in problem solving and creative thinking (Wisker, 2005, p. 196-197).

A study investigating the educational and cultural adjustment of ten Arab Muslim students in Canadian university classrooms indicated that, although taught English before coming to Canada, their knowledge of English did not significantly help them to survive and succeed in their studies. English language in Arabic classrooms is treated as "static rather than living" and emphasizes vocabulary and grammar (Abukhattala, 2004). Similarly, Adams (2004) indicated that international graduate students at an Australian university experienced difficulties in presentations and oral seminars on their proposed research because of lack of self-efficacy that may be a result of language difficulties.

In any attempt to understand the oral communication needs of East Asian graduate students in an American university, it seems that students were most concerned about leading class discussions. Participating in whole-class discussions was their second most difficult academic listening/speaking task, while participating in small-group discussions was their third most difficult task, followed by formal oral presentations. Students also reported they experienced less difficulty participating in small-group discussions than participating in whole-class discussions. Students rated lecture understanding and general listening comprehension as of relatively of high importance when compared to other speaking-related skills, class participation, communication with peers, and communication with professors.

\section{Cultural differences and adjustment}

It is well-known that culture plays a complex and important role in interpersonal relationships. Thus, when students move from their home to another country they will encounter cultural differences that exacerbate difficulties in settling into the new culture (Wisker, 2005, p. 192), on one hand, and affect their interpersonal relationships and adjustment on the other. Both international graduate students and their supervisors should be aware of these cultural differences. Sensitivity to these cultural differences will "help minimize misunderstanding and awkward moments" (Myers, 1993, p.189). Pederson (1991) elaborates on the role of culture in human life as cultural patterns of thought and action directing human ideas and decisions and help people control their lives. People adopt cultural patterns from their parents and teachers. One may or may not realize later in life that his or her culture was only one of many alternative patterns of thinking and acting from which to choose (p. 6).

Although many of the international graduate students are expected to spend considerable time on campus working toward their degrees with clear academic goals, they may not consider what their social lives might be like: Whom will they establish friendships with - their home country mates or those of the host country? How often will they socialize with other students? Will personal characteristics, such as nationality or 
gender, influence their relationships with others? Trice (2004) found out that limited social contact between international graduate students and host nationals is highly affected by student perceptions of the extent to which they have been able to adjust or fit into their new academic and cultural environment.

Selvadurai (1992) investigated the problems of international students at American colleges and universities and concluded that most students came to the United States with their own cultural habits and backgrounds, including the nature of family relationships, patterns of etiquette, food habits and restrictions, and their own religious beliefs. Their movement from their own cultures to a liberal independent culture in America may be a shock to the student. Students may gain effective academic and personal experience through contact with the host community and involvement in its culture.

Alreshoud and Koeske (1997) investigated Arab students' attitudes towards social contact with Americans. Results revealed that most of the Arab students "seldom" or "sometimes" spent free time with Americans. Researchers attribute this to the vast cultural differences between Arabic culture and American culture. Results of a study by Li and Gasser (2005) showe that contact with the hosts and cross-cultural self-efficacy were both related to Asian students' successful socio-cultural adjustment. Similarly, Perrucci and $\mathrm{Hu}$ (1995) examine the satisfaction of international graduate students with their educational and social experiences. They found that married students were more satisfied with social and community relations than were unmarried students. Moreover, McKinley, Pattison and Gross (1996) point out that the extent of cultural differences may cause students to experience culture shock, which refers to the students' reaction to changes in cultural environment.

\section{An overview of the Islamic culture}

Islamic culture takes its origins and principles from the main resources of Islam: the Holy Qur'an and Prophetic traditions (hadiths or sayings). Contradictions that may be found between what is stated in Islamic sources and that is happening in Islamic societies today which is exactly like the contradiction between the theory and practice. Contradictions are present in the conduct of Islamic teachings, not in Islam as a religion. Islamic culture is unique as it takes its fundamentals from divine sources. Long (2005) emphasized the uniqueness of Islamic culture by saying:

Islamic culture is difficult to capture with any precision. Islam has spread to many preexisting cultures throughout the Muslim world; whereas Islamic doctrine itself is uniform and unchangeable, the cultures it has permeated still vary greatly in their traditions, history, intellectual interests and artistic expression. (p. 24)

In addition, Mayor (1998), expresses the originality and comprehensiveness of Islamic culture by indicating that slamic culture, with roots in the past, is still a live today; it also simultaneously developed a conception of the individual and the universe, a philosophy of life and an art of living, which still attests to the prestigious vestiges of its heritage, and which form an integral part of the heritage of humanity.

One of the main features of Islamic culture is its acceptance of others. Therefore, Islam at its beginning "did not seek to fight against the moral attitudes, natural virtues 
and human values of the ancient Arabs, On the contrary, it preached moderation, purification of motives, and good qualities of human nature" (Abu Rida, 1998).

Islam highlights the family as the first and main unit of Islamic society (AlJamali, 1998; Abukhattala, 2004; Hodge, 2002). The family system in Islam achieves balance between the rights of all family members: spouses, children and relatives. It stresses good manners such as mercy, kindness and generosity amongst members of Islamic society. The peace and security offered by a stable family unit is greatly valued and it is seen as essential for the spiritual growth of its members. In addition, Islam emphasizes the parents' status in society and urges children to treat their parents kindly and gently. "In Islam it is not enough to pay for (financially support) one's parents, but a Muslim should act with limitless compassion" remembering their effort with him, or her, whilst a child (Ibrahim, 1997, p. 64). Children's dutifulness to their parents may exceed the limits of parents' lives. For example, after parents' pass away, children may feel obligated to fulfill promises their parents made, or to perform pilgrimage on their behalf (Abou Elfadl \& Inati, 2004, p. 51).

The concept of family in Islam is greatly different from that in western culture. It "comprises not only the two spouses and their children but also the lineage" (Ravane, 1998; Hodge, 2002). Islamic culture stresses the status of children and who are considered as a blessing from Allah. Muslim women have a deep faith in the effect of secure mother-child attachment, as critical to a child's well-being and the structure of Islamic community. Hence, Muslim mothers prefer to spend much time with their children to instill Islamic values and preserve their Islamic heritage (Hodge, 2002).

The unique nature of interpersonal relationships amongst members of Islamic society is another feature of Islamic culture. It is highly valued to respect and honour one's parents and older people. "Muslim children are taught to speak politely to their elders and help with household chores and duties. In some sub-Islamic cultures children are expected to stand when their parents enter a room" as a sign of respect (Abou Elfadl \& Inati, 2004, p.50).

One of the controversial issues in Islam is the status of women in Islamic society. It is a fact that Islam, more than fourteen centuries ago, highlighted the status of women in human society, giving women legal rights equal to those of men. "Islam affirms that all persons, regardless of gender are equal in the sight of God" (Long, 2005, p.36). "Men and women take on together all the responsibilities entrusted to them by God... They are equal patterns in the act of procreation; their good actions and their devotion to Him earn the same esteem in the sight of God" (Al-Dawalibi, 1998, p. 186). Regarding the sexual relationship of men and women, these relations are prohibited unless through marriage. However, "Muslims generally perceive the Western secular emphasis on sexuality as particularly denigrating to women, reducing them to sexual objects or depicting them as commercial entities, and contributing to the breakdown of family and community" (Hodge, 2002).

Education in Islam is not only an individual right, but it is also a required duty upon all capable intelligent and skilled Muslims. By religion, Muslims are required to educate themselves and their children in both religious and worldly fields. One of the main duties of Islamic regimes and governments is to provide, as much as possible, the needed means for their people to earn a better education (Al-Sheha, 2003, p.15). AlJamali (1998) highlights the philosophy of Islamic education in the Holy Qur'an as being 
comprehensive, integrative and evolutionary. It is concerned with the study of the origins of things, their ultimate ends, and the study of relations among human beings, between man and the universe, and between man and Allah, the Creator of the universe. The Qur'an considers existing things (p. 104).

Another feature of Islamic culture is moderation. Islam is a religion of moderation. The emphasis on moderation comes in many texts of the Qur'an and prophetic traditions. Allah says: "Thus have We made of you an Ummah (nation) justly balanced. That you might be witnesses over the nations" (2-143). Among the many examples of the moderation of Islam is its balance between the rights of the individuals and the rights of society, (i.e.) "public and private rights". Individuals in Islamic society enjoy their own rights, and society has its own rights as well. Both rights are controlled by strict rules and conditions. Muslims should believe firmly in such social rights because Allah, who knows best what is suitable for his creations at all time, sets them out (A1Sheha, 2003, p. 50-52). Another example is the prohibition of challenging the beliefs of non-Muslims, "as this provokes the other party to exchange reciprocal challenges. Consequently, this will produce animosity, hatred and dislike between them" (Al-Sheha, 2003, p. 98).

\section{Methodology}

The data for this study was gathered through semi-structured, personal, face-toface tape-recorded interviews with five Arab Muslim graduate students at the U of A. The respondents of the study are two female and three males. Four are in doctoral program and one is in a Masters-level program. The students are from: Egypt, Libya, Oman, Kuwait and Iraq. Two students are enrolled in pharmacy, two are in medicine, and one is in an engineering program. Three have been in Canada for more than two years, two have been here for less than two years. The student respondents were invited to participate in the study through personal contacts in assemblies at the MCE mosque, which is located close to the university campus. Each interview lasted from 30 to 45 minutes and covered the experiences of these Arab Muslim students at the U of A concerning their cultural adjustment, language difficulties, supervision, differences of study system, and funding. The participants were invited to use either Arabic or English, and chose to use either pure Arabic or to combine Arabic with English to better express themselves. The data was analyzed thematically. Themes emerged both inductively and deductively from the data. The nature of the selection technique (i.e., purposive sampling) prevents posing generalizations. This work is useful in that it provides insights to specific Arab Muslim individual student experiences while engaged in graduate studies at the $\mathrm{U}$ of $\mathrm{A}$.

\section{Findings and discussion}

The following themes emerged from analyzing the interviews:

\section{Reason chosen to come to Canada}

Choosing a country to study and live in is a highly important issue from the perspective of Arab international students. This choice may be made by a sponsor, such as those students sponsored in their country of origin, or, in some instances, by the student him- or herself. Self-funded students make their own decision. In the case of Muslim students, a majority of them, and their sponsors, prefer to study in Canada 
following the events of September Eleven. Two students indicated their sponsors made a decision on their behalf, while the remaining three indicate they chose to come to Canada as it was easier and safer after September 11, 2001. A student stated:

The atmosphere in Canada is more social than in the United States of America, and it is so difficult to be accepted in the American universities especially after September 11, even if you are eligible.

\section{Reason for preferring to study at the $\mathbf{U}$ of $\mathrm{A}$}

Since the U of A has many pull factors, it attracts many international students. Students preferred to gain admission to the $\mathrm{U}$ of A due to its prominent academic reputation, the diversity of specializations it offers, the ease of administrational procedures, and low tuition fees. In addition, the $U$ of A serves more than 35,500 students in more than 200 undergraduate and 170 graduate programs. It has 295 active linkages in fifty-one countries and more than 2,250 international students from more than 110 countries on study permits. It is among the top five Canadian universities in annual total research funding as indicated by the Canadian Institutes of Health Research, the Natural Sciences and Engineering Research Council and the Social Sciences and Humanities Research Council. Furthermore, it has 24 professors who have received national 3M Teaching Fellowships - Canada's highest award for undergraduate university teaching excellence (University of Alberta Facts, 2005-2006). All respondents indicated that they chose to study at the $\mathrm{U}$ of A because of its academic reputation in their fields of study, in addition to the ease of acceptance procedures. A student said:

It was my dream to study in the University of Toronto, as it was the first place where I lived and studied in Canada, but because of some administrative difficulties there, my professor advised me to go to the $U$ of $A$ as it has a very great academic reputation in my specialization. In addition, the administrative procedures were easier in the $U$ of $A$ than in other Canadian universities.

\section{Differences in academic systems}

All respondents referred to the huge differences between the academic system at the $\mathrm{U}$ of $\mathrm{A}$ and that of the universities where they have been educated in their home countries. Main differences appear in the following subcategories.

\section{Nature of study}

Independence, practice and academic freedom are the main features of postgraduate study in the developed countries (Barker, 1997, p. 118-119). Respondents stated that study the $\mathrm{U}$ of $\mathrm{A}$ is more productive than study in their home countries. This is because the study at the $U$ of $A$ is practical and supervisors encourage students to be creative and critical, rather than being limited to the memorization of facts. A student stated:

The study here in $U$ of $A$ pays more attention to practice rather than memorization, and this gives the student more experience through being independent and learning things by himself or herself while a supervisor works as a guide or facilitator. 
However, another student did not accept this as factual and connected this to other factors such as the nature of the course, student learning strategies, and, teaching methods and preferences of the supervisor. The nature of study affects the examination process, whether practical or theoretical. A student indicated that, in his or her country, they do not have open book exams. All exams are closed book and students need rely on memorization to recall information during examinations. Furthermore, proving one's knowledge and abilities at the $\mathrm{U}$ of $\mathrm{A}$, exceeds beyond just passing exams and extends to publishing of papers, delivering conference presentations and participating in classroom discussions.

\section{Study facilities}

The $U$ of A provides a first-class learning environment through its facilities. These facilities include a main campus covering approximately fifty city blocks, with more than ninety buildings, additional land off campus for research, and more than four hundred distinct research laboratories, research stations and centers. The $U$ of $A$ is home to the largest shared-memory computer in Canada. The library is Canada's second-largest research library, ranked first in volumes per student with 5.7 million volumes, with access to more than 10,000 full-text electronic journals, and more than six hundred electronic databases (U of A Facts 2005-2006). All respondents agree that there are huge differences between available study facilities at the $U$ of $A$ and those in their home countries. These facilities give instructors the ability to teach a number of extensive courses as it is easy for their students access resources.

\section{Supervisory relationship}

The supervisory relationship between a student and their supervisor is a crucial issue because it is highly valued in the Arabic and Islamic countries. Although it is assumed that supervisors will play a significant role in building this relationship through social events, Muslim students may be unable or unwilling to participate in such events because of their religious beliefs and cultural habits (Delamont, Atkinson \& Pary, 2004, p. 191). Respondents indicate the relationship with supervisors in the $U$ of $A$ is mainly restricted to academic dimensions while in their home countries this relationship may exceed these limits to include social and, sometimes, financial matters. Another point indicated by one of the respondents is that, at the $U$ of $A$, a supervisor and other faculty members respect students' opinions and reflect upon their points of view. The respondents stressed that, in their countries, supervisors' opinions are always (correct) and not open to debate. A student indicated that:

In my country my main job is to follow what my supervisor tells me (similar to close your eyes and follow me) but here my supervisor just guides me and leaves me to discover facts on my own. Sometimes he treats me cruelly but I know this is a kind of teaching.

Arab Muslim graduate students, like other international students, may find it hard to adjust to the relative informality of the academic relationship at the $U$ of $A$. Todd (1997) indicates that international graduate students appreciate this informality as it provides a scope for discussion (p. 178). Respondents indicated the informal academic 
and supervisory relationship at the $U$ of A was not a problem and that they could easily adjusted to the relationship. Moreover, they reported that they appreciated this type of relationship.

\section{Cultural differences and adjustment}

It is well known that there is great dissimilarity between Islamic and Arabic culture and Canadian and western cultures (Selvadurai, 1992; Alreshoud and Koeske, 1997). Although Canadian culture is multi-national, it differs from the Islamic and Arabic culture. All respondents reported that there are huge cultural differences between their home countries and Canada. Among these differences is the nature of Canadian society. A student said:

The Canadian society is open and all topics can be tackled and discussed. There is no absolute right and absolute wrong. I think this is an advantage as we just discuss and at the end, I am free to choose what I am comfortable with.

The nature, content, context and topics of everyday conversation represent cultural differences (Eland, 2001). In Arabic culture, there are topics that are difficult to discuss, such as debating religious beliefs or sexuality related topics especially between genders. Respondents expressed difficulty in participating in some types of conversations.

Respondents observed the nature of social relationships in Canadian society inside and outside the university as a significant cultural difference. While four students stressed the beneficial nature of interpersonal relationships, one student disagreed as these relationships shapes the nature of relationships in all societies. The old and aged people are highly valued in Islamic and Arabic culture (Ibrahim, 1997, p 64; Abou Elfadl \& Inati, 2004, p. 51). Independence is a main feature of Canadian culture, even when one is aged, while in Islamic and Arabic culture it is an aspect of piety to help and serve others, especially the aged. A student referred this cultural difference by saying:

It hurts my feelings when I see an aged man or woman in supermarkets pushing with difficulty the cart to do the shopping on his or her own. In my country, aged people find their sons and daughters in their service. Moreover, children are proud to serve their aged parents.

However, another student disagreed with this perspective and considered reliance as a kind of dependence.

\section{Isolation and alienation}

Although the literature indicates that international students suffer from isolation and alienation (Mostafa, 2001, p. 84-86), respondents indicated they only felt alienation upon their arrival at university in Canada. As Arab Muslim students prefer to interact with their country mates and other Muslim students (Alreshoud \& Koeske 1997; Hodge 2002), students alleviated feelings of alienation and isolation, either through socializing with the larger Arab Muslim community in Edmonton, or by interacting with colleagues from their own, or other, countries having similar cultural and habitual principles constituting sub-cultural groups. A student said: 
I do not feel isolation or alienation because of the nature of the Canadian community. It is a multi-national and multi-cultural community and all people respect each other. But I really miss my friends and relatives. In addition, I do not feel that because there are many Arabs and Muslims inside and outside the university.

Another student said:

Before coming to Canada, I spent five years in another Arab country and I never felt isolation. When I came to Canada, I was so isolated that I had depression and received medical treatment. Now after five years in Canada everything is ok.

\section{English language difficulties:}

As revealed from the literature dealing with international students studying in a language other than one's mother tongue, one of the main difficulties for students is to experience difficulties in the foreign language either on- and/or off-campus (Selvadurai, 1992; Cammish, 1997; Macrae, 1997). Although English is widespread as a second language in many Arab countries, Arab graduate students face language difficulties (Abukhattala, 2004). All respondents indicate the English language is one of the crucial issue that impact them either on- or off-campus. It is difficult to understand a wide range of accents, use of slang, or dialectical variations. A student expressed difficulty in getting people to understand her/him:

It is sometimes difficult to express myself in English and I think people find it difficult to understand me. For example, I went to another lab in my faculty to ask them how can I download several files on one CD, but they did not get what I wanted. I repeated my question three times but they did not understand me, so I left without any reply.

The cultural context in which the conversation takes place may make it even more difficult for a student to be understood. Furthermore, the accent of the international student may affect their ability to communicate with others freely and efficiently and may cause problems for the student.

\section{Conclusions and recommendations}

To conclude, the present study addresses an important topic as Muslim graduate students represent a unique group at academic institutions due to the nature of Islamic and Arabic culture, which students may neither ignore or abandon. The presence of Arab Muslim students enhances cultural diversity, a main features of Canada in general, and, specifically, as students at the $U$ of A. Although the $U$ of A has many programs and strategies to assist international students, Muslim students require specific attention and a tailored orientation to assist them in accepting and adjusting to Canadian society. The results of this study will provide supervisors, Arab Muslim graduate students at the U of $\mathrm{A}$, and students affairs practitioners to better understand the cultural and educational backgrounds of the Muslim community, in general, and of the students, in particular.

Despite considering social and cultural adjustment as a crucial issue for international students, this does not necessarily represent a problem for Arab Muslim graduate students at the $\mathrm{U}$ of $\mathrm{A}$ due to the multicultural nature of Canada, presence of 
Islamic social and cultural organizations in Canada, and the cultural sub-groups of Muslims and Arabs within Canadian society. Furthermore, these factors diminish problems relating to English language proficiency. Although there are slight differences amongst Arabic educational systems, resulting in similarities in research participant cultural and educational backgrounds, the students appreciate their experiences at the $\mathrm{U}$ of A that encouraged them to think critically and study practically. Moreover, the presence of the Arab Muslim students in the U of A may help in correcting the image of Islam as a religion, often distorted in the west, through direct interaction, both academically and socially with other students.

To enrich the learning and cultural experiences of Arab Muslim graduate students at the $\mathrm{U}$ of $\mathrm{A}$, the study recommends the following: To ehance international student orientation delivered by the university to include an introduction to Canadian mainstream culture and topics related to Arab Muslim students in Canada such as mosques, Islamic and Arabic organizations in Canada, halal (Islamic prepared and accepted) food and drinks, and Islamic social events. Urging students, both domestic and international, to understand and accept each other's beliefs, culture and habits through awareness of the culturally diverse nature of Canada in general, and the U of A, in particular. English language proficiency difficulties may be addressed through several strategies including the introduction of English for academic purposes programs, urging students to participate in seminars and classes, and an orientation to the cultural features of the English language..

As supervisors are the primary contact for their students and represent the main source of student support, supervisors of Arab Muslim graduate students should take into consideration the nature of Islamic culture as influencing student behaviors, and, particularly when supervising students of a different gender. In addition, departments may enrich the experiences of Arab Muslim graduate students through academic and social events that open conversations and discussions amongst all departments and students towards constituting a healthy and culturally diverse academic environment. 


\section{References}

Abukhattala, I. (2004). Educational and cultural adjustment of the Arab Muslim students in Canadian university classrooms, (Doctoral Dissertation, McGill University, 2001).

Abou Elfadl, K. \& Inati, S. (2004). Introducing Islam: What Muslims think and how they live. Jordan, Mason Crest Publishers.

Abu Rida, M. A. (1998). Norms and values. In Abdelwahab Bouhdiba \& Muhammad M. al-Dawalibi (Eds.), the different aspects of the Islamic culture: the individual and society in Islam (pp. 19-59). Paris: UNESCO.

Adams, K. (2004). Modelling success: enhancing international postgraduate research students' self-efficacy for research seminar presentations. Higher Education Research and Development, 23 (2), 115-130.

Al-Dawalibi, M. (1998). The emancipation of women: a continuing priority. In Abdelwahab Bouhdiba \& Muhammad M. al-Dawalibi (Eds.). The different aspects of the Islamic culture: the individual and society in Islam, (pp. 185-202). Paris: UNESCO.

Al-Jamali, M. (1998). Islamic education. In Abdelwahab Bouhdiba \& Muhammad M. alDawalibi (Eds.). The different aspects of the Islamic culture: the individual and society in Islam” (pp. 137-183). Paris: UNESCO.

Alreshoud, A. \& Koeske, G. (1997). Arab students' attitudes toward and amount of social contact with Americans: a causal process analysis of cross-sectional data. Journal of Social Psychology, 137 (2), 235-245.

Al-Sheha, A. (2003). Misconception on human rights in Islam, Translated by Mohammed Said/ Riyadh: Safeer Press.

An-Nawawy, Y. (1997). Riaad As-Saleheen. (in Arabic) Cairo: Dar Alhadeeth.

Barker, J. (1997). The purpose of study, attitudes to study and staff-student relationships. In McNamara, D. \& Harris, R. (Eds.). Overseas Students in Higher Education: Issues in Teaching and Learnin, (pp.108-123). London: Routledge.

Barmeyer, C. (2004). Learning styles and their impact on cross-cultural training: An international comparison in France, Germany and Quebec. International Journal of Intercultural Relations, 28, 577-594.

Bullen, E. \& Kenway, J. (2003). Real or imagined women? Staff representations of international women postgraduate students. Studies in the Cultural Politics of Education, 24 (1), 35-50. 
Cadman, K. (2000). Voices in the air: evaluations of the learning experiences of international postgraduates and their supervisors. Teaching in Higher Education, 5(4), 475-491.

Cammish, N. (1997). Through a glass darkly: problems of studying at advanced level through the medium of English. In McNamara, D. \& Harris, R. (Eds.). Overseas Students in Higher Education: Issues in Teaching and Learning, (pp.143-155). London: Routledge.

Delamont, S.,Atkinson, P. \& Parry, O. (2004). Supervising the doctorate: a guide to success, (2nd ed.), Berkshire: SRHE and Open University Press.

Epstien, D., Boden, R. \& Kenway, J. (2005) Teaching and supervision. UK: Sage.

Eland, A. (2001). Intersection of academics and culture: The academic experience of international graduate students. (Doctoral Dissertation, University of Minnesota.)

Green, H. \& Powell, S. (2005). Doctoral study in contemporary higher education, UK: SRHE \& Open University Press.

Hodge, D. (2002). Working with Muslim Youths: Understanding the values and beliefs of Islamic discourse. Children and schools, 24(1),6-20.

Humfrey, C. (1999). Managing International Students. Buckingham: Open University Press.

Ibrahim, I. A. (1997). A Brief illustrated guide to understanding Islam, Texas: Darussalam.

Kuo, B.\& Roysircarb, G. (2006). An exploratory study of cross-cultural adaptation of adolescent Taiwanese unaccompanied sojourners in Canada. International Journal of Intercultural Relations, 30, 159-183.

Li, A. \& Gasser, M. (2005). Predicting Asian international students' sociocultural adjustment: A test of two mediation models. International Journal of Intercultural Relations, 29, 561-576.

Leder, G. \& Forgasz, H. (2004). Australian and international mature students: the daily challenges. Higher Education Research and Development, 23(2), 183-198.

Long, D. (2005). Cultures and customs of Saudi Arabia, USA: Greenwood Press.

Macrae, M. (1997). The induction of international students to academic life in the United Kingdom. In McNamara, D. \& Harris, R. (Eds.). Overseas students in higher education: issues in teaching and learning, (pp.127-142). London: Routledge. 
Maheshwari, B. \& Malfroy, J. (2001). looking through the fog: making sense of overseas student supervision in Australian universities. In A. Bartlett \& G. Mercer (Eds.). postgraduate research supervision: transforming relations (pp. 255-260). New York: Peter Lang Publishing.

Mayor, F. (1998). Preface of the second volume, In Abdelwahab Bouhdiba \& Muhammad M. Al-Dawalibi (Eds) The Different aspects of the Islamic culture "The individual and society in Islam". Paris: UNESCO.

Mckinlay, N., Pattison, H. \& Gross, H. (1996). An exploratory investigation of the effects of a cultural orientation programme on the psychological well-being of international university students. Higher Education, 31, 379-395.

Mostafa, G. (2001). (in Arabic) The problems of the international students in Al-Azhar university: a field study. Unpublished MA thesis. Al-Azhar University: Egypt.

Mostafa, G. (2004). [in Arabic] The roles of postgraduate supervisors in the Egyptian faculties of education in the light of their competencies: an evaluative study, (Doctoral dissertation, Al-Azhar University, Egypt, 2004.)

Myers, D. G. (1993). Social psychology, (4th Ed.), New York: McGraw-Hill.

Myles, J. \& Cheng, L. (2003). The social and cultural life of non-native English speaking international graduate students at a Canadian university. Journal of English for Academic Purposes, 2, 247-263.

Nelson, C., Nelson, J \& Malone, B. (2004). Predicting success of international graduate students in an American university. College and University Journal, 80(1), 19-27.

Pederson, P. (1991). Multiculturalism as a generic approach to counseling, Journal of Counseling and Development, 70, 6-11.

Perrucci, R.,\& Hu, H. (1995). Satisfaction with social and educational experiences among international graduate students. Research in Higher Education, 36(4), 491-508.

Ravane, M. (1998). The family bases in the Islamic city. In Abdelwahab Bouhdiba \& Muhammad M. al-Dawalibi (Eds.). The different aspects of the Islamic culture: the individual and society in Islam, (pp. 117-135). Paris: UNESCO.

Scheyvens, R., Wild, K. \& Overton, J. (2003). International students pursuing postgraduate study in geography: impediments to their learning experiences. Journal of Geography in Higher Education, 27(3), 309-323.

Selvadurai, R.(1998). Problems faced by international students in American colleges and universities. Community Review, 16, 153-158. 
The National Academies (2005). Policy implications of international graduate students and postdoctoral scholars in the United States. USA: The National Academies Press.

Todd, E. S. (1997). Supervising overseas students: problem or opportunity. In McNamara, D. \& Harris, R. (Eds.). Overseas students in higher education: issues in teaching and learning (pp.173-186). London: Routledge.

Trice, A. (2004). Mixing it up: international graduate students' social interactions with American students. Journal of College Student Development, 45(6), 671-687.

UMBC Office of Institutional Research (2000). Graduate student satisfaction survey. Baltimore County: University of Maryland.

University of Alberta (2005). University of Alberta Facts 2005-2006. Available on line. Retrieved May 1, 2006, from http://www.uofaweb.ualberta.ca/facts/

Wisker, G. (2005). the good supervisor: supervising postgraduate and undergraduate research for doctoral theses and dissertations. New York: Palgrave MacMillan.

Yeh, C. \& Inose, M (2003). International students' reported English fluency, social support satisfaction, and social connectedness as predictors of acculturative stress, Counseling Psychology Quarterly, 16 (1), 15-28. 